boys' and girls' schools, will be more than doubled by 1956 . In order to provide the teachers required for this expansion, provision has been made to increase the yearly output of trained teachers by the establishment of new training centres. Secondary and intermediate education is also to be developed by increasing the number of government intermediate schools, although the rapid expansion of girls' intermediate education will not be possible at present owing to the lack of qualified staff. Adult education is to be developed side by side with the expansion of schools; there is to be an increase in the number of after-care clubs attached to certain elementary schools; the Gezira experiments among adult villagers are to be extended, and mass literacy campaigns, on the lines of experiments already carried out, are to be conducted in new areas. The plan also incorporates a comprehensive scheme for technical and commercial education, which includes pre-apprenticeship schools, evening classes, and training of selected candidates at a central technical school. A Technical Institute is to be founded at Khartoum.

In order to implement these proposals, a number of non-Sudanese will have to be employed, but simultaneously steps are being taken to replace non-Sudanese officials by sending selected graduates of Gordon Memorial College abroad, to England and Egypt, to obtain degrees; in addition teachers are being sent abroad on short courses.

\title{
Sierra Leone Protectorate Literature Bureau
}

THE report of the Literature Bureau for 1949 describes literacy campaigns conducted in Nongowa chiefdom, where teaching has been carried on during the year by five paid teachers and a total of I,I I I reading certificates have been awarded. In Dama chiefdom the paid teachers have been withdrawn at the request of the Paramount Chief and the work has been carried on by voluntary teachers under a Chiefdom Committee. About one-seventh of the adult population of this chiefdom are now literate. A literacy campaign was started in Kpanga chiefdom by eight young men, who after training at Bo were stationed in various sections, one of the teachers who had served at Dama being appointed supervising teacher. By the end of the year 425 reading certificates had been awarded to new literates. In this chiefdom and in Dama, Sande girls are being taught to read. In other chiefdoms voluntary work by missions has continued.

The Bunumbu Press has published twelve books during the year, one in Temne and the others in Mende, making a total of 54,000 books in Mende and 8,000 in Temne. There are also 25 manuscripts ready for printing. Figures of sales and income from sales show a rapidly increasing demand for books, the average annual expenditure per literate in 1949 being I $s .8 d$. with the average price of books at $s d$. per book. Most of the sales are effected through the central stations of the Mission; in the campaign areas a mobile bookshop has been of great value.

Since the majority of the new adult literates are in the smaller towns and villages, and constitute for the most part the younger section of the farming community, it would be as well if this could be followed up by literature of special interest to farmers, and also if possible by efforts, such as the encouragement of community centres, to make village life more interesting.

\section{Bantu Studies in South Africa}

A faculty of Bantu studies is to be established at the Potchefstrom University College this year under the supervision of Dr. F. R. Lehmann, for many years a teacher of anthropology at the University of Leipzig, Germany, who has been associated with the Department of Native Affairs for ro years. A conservatoire of music, under Mr. C. Roode, for some time superintendent of music of the Transvaal Education Department, has also been opened. 